\title{
Prevalence of elevated milk $\beta$-hydroxybutyrate concentrations in Holstein cows measured by Fourier-transform infrared analysis in Dairy Herd Improvement milk samples and association with milk yield and components
}

\author{
D. E. Santschi, ${ }^{1}$ R. Lacroix, J. Durocher, M. Duplessis, R. K. Moore, and D. M. Lefebvre \\ Valacta, 555, boul. Des Anciens-Combattants, Ste-Anne-de-Bellevue, Québec, H9X 3R4, Canada
}

\begin{abstract}
The purpose was to describe the prevalence and effect of elevated milk $\beta$-hydroxybutyrate (BHB) as detected by routine Fourier-transform infrared analysis in Dairy Herd Improvement milk samples. Data collected over 4 yr included cow information as well as milk yield and composition from 498,310 samples from postparturient Holstein cows (5-35 d in milk) from 4,242 herds. The following thresholds were used to classify cows based on their early lactation milk BHB concentration: $<0.15$ $\mathrm{mmol} / \mathrm{L}=$ negative; 0.15 to $0.19 \mathrm{mmol} / \mathrm{L}=$ suspect; and $\geq 0.20 \mathrm{mmol} / \mathrm{L}=$ positive. Overall prevalence (suspect + positive) was $22.6 \%$ and was higher for older cows $(18.7,19.5$, and $27.6 \%$, for cows in their first, second, and third or greater lactation, respectively). Distribution with regards to days in milk was different among parity groups, with first-lactation cows having highest prevalence (30\%) in the first week after calving; cows in their second and third and greater parity had the highest prevalence in the second week after calving, at 25.8 and $34.6 \%$, respectively. Season of calving affected the prevalence of elevated milk BHB, with cows calving in the fall and spring seasons showing higher prevalence. Distribution among herds was highly variable, as $45 \%$ of herds had a prevalence of $20 \%$ or less, $47 \%$ of herds had a prevalence between 21 and $40 \%$, $6 \%$ of herds had a prevalence between 40 and $50 \%$, and $2 \%$ of herds had a prevalence of $50 \%$ or above. Positive cows had lower milk yield, protein concentration and yield, and lower Transition Cow Index than negative cows, but also higher fat concentration and yield, as well as higher somatic cell count than negative cows. Suspect cows were generally intermediate. The present analysis highlights the opportunity for elevated milk BHB monitoring at the herd level through routine BHB testing in Dairy Herd Improvement milk samples.
\end{abstract}

Received March 3, 2016

Accepted July 8, 2016.

${ }^{1}$ Corresponding author: dsantschi@valacta.com
Key words: $\beta$-hydroxybutyrate, DHI milk sample, Holstein cow

\section{INTRODUCTION}

Most cows experience some level of negative energy balance during early lactation when the energy demand for milk production cannot be met by intake (Herdt, 2000; Duffield et al., 2009). Some level of ketone elevation postcalving is part of a normal adaptive response (Duffield et al., 2009), but cows unable to adjust to this transition develop hyperketonemia, a disorder defined as a high concentration of ketone bodies such as BHB, acetone, and acetoacetate in the blood (Herdt, 2000). Recent studies report population incidence of hyperketonemia ranging from 25 to $60 \%$ (McArt et al., 2013; Mahrt et al. 2015; Vanholder et al., 2015).

Hyperketonemic cows are more likely to develop clinical ketosis (Duffield et al., 2009; Seifi et al., 2011; Suthar et al., 2013), health issues (LeBlanc et al., 2005; Duffield et al., 2009; Ospina et al., 2010a), lower milk production (Dohoo and Martin, 1984; Ospina et al., 2010b; Suthar et al., 2013), and impaired reproduction (Walsh et al., 2007; Koeck et al., 2014a), which have been reviewed in recent studies (Raboisson et al., 2014; McArt et al., 2015). As a result, hyperketonemia also leads to increased culling rate (Seifi et al., 2011; McArt et al., 2012), and economic losses are estimated around $\$ 289$ per case (McArt et al., 2015).

The gold standard test for hyperketonemia is blood BHB (Oetzel, 2004), as BHB is the predominant circulating ketone body in ruminants. Several studies have evaluated the BHB concentration threshold at which future health, production, or reproduction is impaired. Among those, Duffield et al. (2009) suggested a serum BHB concentrations of $1.2 \mathrm{mmol} / \mathrm{L}$ during the first 2 wk of lactation as a cut-point above which production and disease incidence are affected. LeBlanc et al. (2005) suggested that risks of displaced abomasum increased at serum concentrations above $1.2 \mathrm{mmol} / \mathrm{L}$. Suthar et al. (2013) recommended an optimum blood threshold level $\geq 1.1 \mathrm{mmol} / \mathrm{L}$ as a predictor for lameness and clinical 
ketosis, $\geq 1.4 \mathrm{mmol} / \mathrm{L}$ for metritis, and $\geq 1.7 \mathrm{mmol} / \mathrm{L}$ for displaced abomasum. Overall, most published studies support the recommendations of a universal blood BHB threshold of $1.2 \mathrm{mmol} / \mathrm{L}$.

For convenience purposes, cow-side tests are available to test individual cows for elevated BHB either through milk (Keto-Test, Elanco Animal Health, Greenfield, IN) or blood (Precision Xtra, Abbott Diabetes Care, Alameda, CA) with good precision (Iwersen et al., 2009; Pineda and Cardoso, 2015), although accuracy of milk BHB has been questioned (Oetzel, 2004). Moreover, these individual cow tests are time-consuming and expensive if used as a whole-herd screening tool for assessing prevalence. Other data, such as DMI (Goldhawk et al., 2009) and standing behavior (Itle et al., 2015), can also be used for screening cows at risk of developing ketosis, but these require specialized devices and are labor- and time-consuming and, therefore, not easy to implement on farms. In addition, such data will mainly detect clinical cases and might omit subclinical cows. Routine infrared analysis of BHB concentration in milk DHI samples provides a fast, low-cost, and reliable alternative to blood BHB analysis and could be used as a herd diagnosis tool for elevated milk BHB prevalence (Denis-Robichaud et al., 2014).

The objective of the present paper was to describe the prevalence and effect of elevated milk BHB as detected by routine Fourier-transform infrared testing in DHI milk samples on dairy farms in eastern Canada. More specifically, our aim was to describe the distribution according to parity, season, and herd, as well as the effect on test-day milk yield and components.

\section{MATERIALS AND METHODS}

\section{Data Source, BHB Analysis, and Threshold Levels}

Cow information, test-day production data, Transition Cow Index (TCI; Nordlund, 2006), and milk BHB concentrations analyzed by Fourier-transform infrared were obtained by the Valacta database (Dairy Centre of Expertise for Eastern Canada, Sainte-Anne-de-Bellevue, Quebec, Canada) from October 2011 to October 2015. Only samples from early-lactation cows (DIM 5-35) were used for analysis. The data set included a total of 498,310 Holstein cows from 4,242 herds in Quebec, Canada: 160,553 (32.2\%) were first-lactation cows, 132,914 (26.6\%) were second-lactation cows, and 204,843 (41.1\%) were third-lactation or greater cows. All cows had a single observation per lactation. Milk samples were analyzed as regular DHI milk samples for fat, protein, lactose, MUN, and SCC in addition to BHB concentrations. Analyses were performed using a Foss MilkoScan FT 6000 for infrared evaluation of milk component, combined with a Fossomatic FC for SCC analysis (Foss Electric A/S, Hillerød, Denmark). Calibrations for BHB infrared analyses were developed with a continuous flow analyzer $\left(\mathrm{San}^{++}\right.$Skalar, Breda, the Netherlands) as described by Denis-Robichaud et al. (2014) and de Roos et al. (2007). The following thresholds were used to classify cows based on their early lactation milk BHB concentration: $<0.15 \mathrm{mmol} / \mathrm{L}$ $=$ negative (NEG); 0.15 to $0.19 \mathrm{mmol} / \mathrm{L}=$ suspect (SUSP); and $\geq 0.20 \mathrm{mmol} / \mathrm{L}=$ positive $(\mathbf{P O S}$; DenisRobichaud et al., 2014). Cows classified as SUSP and POS were considered to have elevated milk BHB concentrations. To calculate herd prevalence levels, only herds with at least 20 cows with $\mathrm{BHB}$ concentration results between 5 and 35 DIM during the experimental period were included $(\mathrm{n}=3,349)$. Energy-corrected milk was calculated as ECM $(\mathrm{kg} / \mathrm{d})=12.55 \times$ fat $(\mathrm{kg} / \mathrm{d})+7.39$ $\times$ protein $(\mathrm{kg} / \mathrm{d})+0.2595 \times$ milk yield $(\mathrm{kg} / \mathrm{d})$. This equation was derived from the NRC (2001) equation for $\mathrm{NE}_{\mathrm{L}}$, considering the energy value of milk as $0.74 \mathrm{Mcal} /$ $\mathrm{kg}$ of milk, as determined by Tyrrell and Reid (1965).

\section{Statistical Analysis}

Results for the same cow but for different lactations were considered as independent values to assess population prevalence in eastern Canadian Holsteins. Distribution and prevalence of elevated milk BHB were estimated using the FREQ and UNIVARIATE procedures of SAS (version 9.4, SAS Institute Inc., Cary, $\mathrm{NC}$ ). Effects on test-day milk production and components, SCC, and TCI were assessed using the MIXED procedure of SAS. Fixed effects included in the model were BHB status (NEG, POS, or SUSP), parity (first, second, and third or greater), DIM, calving month, and the interaction between BHB status and parity. Herd was used as a random effect. Least squares means were estimated for BHB status and parity interaction, and differences were tested with the Bonferroni adjustment. Effects were considered significant at $P \leq 0.05$.

\section{RESULTS AND DISCUSSION}

According to the Foss Ketosis application note (Foss, 2009), a threshold of $0.15 \mathrm{mmol} / \mathrm{L}$ for BHB yields a sensitivity of $96 \%$ and specificity of $89 \%$. It must be noted that the Foss calibration for BHB is semiquantitative, as stated in Foss (2015). Accordingly, results presented in the current paper are relative to elevated milk BHB concentrations alone as a herd-level screening tool for assessment of energy status in early-lactation cows. 


\section{Parity and DIM Prevalence}

Over the 4 yr of data collection, median herd size was 62 cows (range $=35-766$ ) and median number of samples tested by herd was 117 (range $=20-2,673$ ). The wide range reflects the decision of each producer whether to test for BHB or not on a monthly basis over 4 yr. Average DIM at first test were 20.6, 18.2, and 19.1 (SD = 8.9) for NEG, SUSP, and POS cows, respectively. Overall elevated milk BHB prevalence in the studied population was $22.9 \%$, with 12.0 and $10.9 \%$ for SUSP and POS BHB categories, respectively. Average prevalence between DIM 5 to 35 was different according to parity as was distribution of prevalence by DIM $(P<0.01 ;$ Figure 1$)$. During this early lactation period, average prevalence of elevated milk BHB concentration for first-lactation cows was $18.8 \%$, with the highest prevalence $(30.3 \%)$ in the first week postpartum. Regarding second-lactation cows, average prevalence from DIM 5 to 35 was $19.5 \%$, with the highest prevalence between DIM 13 and 15 (25.8\%). Average prevalence for cows in their third or greater lactation from 5 to 35 DIM was $27.6 \%$, with the highest prevalence between DIM 11 to $14(34.6 \%)$.

Reported prevalence of elevated BHB in the literature vary as a result of detection method used, fluid tested (serum or blood vs milk), testing frequency, and DIM at testing. In addition, we noted an important distinction to be made between prevalence (number of existing cases divided by number of cows sampled) and incidence (number of new cases divided by the number of cows at risk). McArt et al. (2012) reported an average incidence of hyperketonemia of $43 \%$, ranging from 26 to $56 \%$, with peak incidence at 5 DIM when $22.3 \%$ of cows had their first positive result. Peak prevalence was also at 5 DIM when $28.9 \%$ of cows were positive. In our trial, cows from 4 herds were tested 6 times (Mondays, Wednesdays, and Fridays) between 3 and 16 DIM; blood BHB concentration was the studied variable. Of the 252 cows involved in the study by Mahrt et al. (2015) tested twice a week from calving to 42 DIM, $53.2 \%$ had at least 1 positive result (incidence); diagnosis was made based on blood BHB concentration. Vanholder et al. (2015) analyzed serum from 1,715 Holstein cows between 7 and 14 DIM in 23 dairy herds and reported an overall incidence of hyperketonemia (BHB of $1.2-2.9 \mathrm{mmol} / \mathrm{L}$ ) of $47.2 \%$, similar to the previously mentioned studies. Suthar et al. (2013) reported an overall prevalence of hyperketonemia of $21.8 \%$ among 10 European countries, ranging from 11.2 to $36.6 \%$. Garro et al. (2014) tested postparturient cows between 4 and 19 DIM on pasture and reported a prevalence of hyperketonemia of $10.3 \%$, similar to Mahrt et al. (2015), who observed weekly prevalence of 9.6 to $14.6 \%$

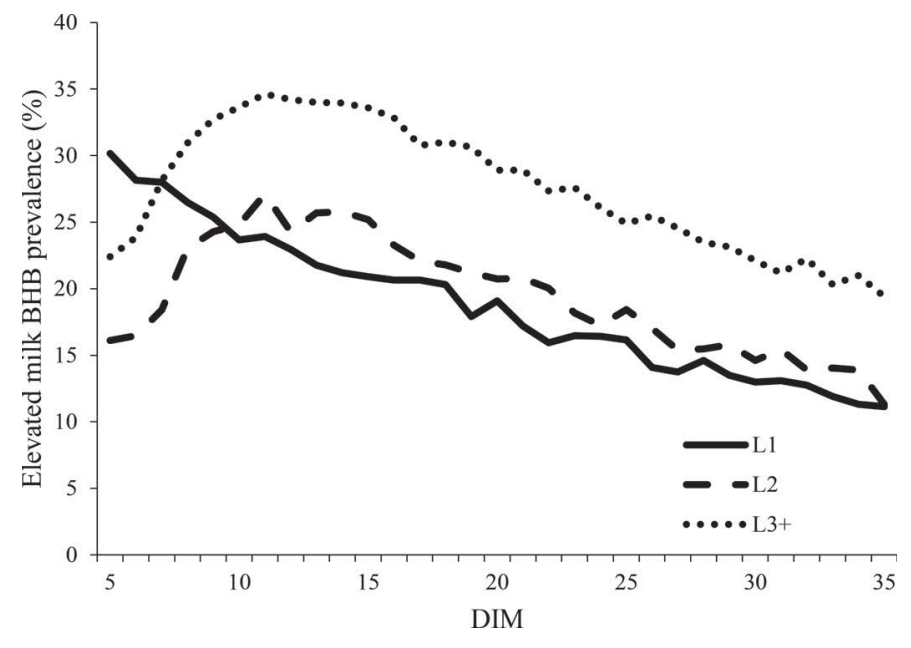

Figure 1. Prevalence of elevated milk BHB in early-lactation cows (5-35 DIM) according to parity. L1 = first-lactation cows (n $=160,553) ; \mathrm{L} 2=$ second-lactation cows $(\mathrm{n}=132,914)$; L3 = thirdlactation cows $(\mathrm{n}=204,843)$. Parity $\times$ DIM, $P<0.01$.

over the first $7 \mathrm{wk}$ of lactation. In contrast to the present study, all of the previously cited trials measured BHB concentration in blood. Still, proportion of cows detected with high BHB concentrations in milk in the present study are similar to previous trials analyzing blood.

The design of the present study, with samples collected on a monthly basis and a single measure for cows between 5 and 35 DIM, did not allow direct assessment of population incidence. It has been suggested that incidence of hyperketonemia could be evaluated by multiplying the prevalence by a factor of 2.0 to 2.5 (McArt et al., 2013). This calculation was made empirically from 2 large data sets (Duffield et al., 1999; J. McArt, D. Nydam, and G. Oetzel, University of WisconsinMadison, unpublished data; G. Oetzel, University of Wisconsin-Madison, personal communication), and based on blood concentrations of BHB. Whether or not this prevalence-to-incidence factor is the same for milk $\mathrm{BHB}$ as for blood BHB has not been demonstrated and was not determined in the present study. For discussion purposes, applying this blood BHB factor to our milk BHB concentrations would yield a population incidence between 46 and $57 \%$ for eastern Canadian dairy cows, which is similar to previous reports in the United States (McArt et al., 2012) and Europe (Vanholder et al., 2015). Conversely, the study by Mahrt et al. (2015) reported a prevalence-to-incidence factor of approximately 4.5 . As highlighted by these authors, the incidence depends on the period examined, and simply doubling the prevalence might be erroneous. However, applying their factor to the present prevalence rate would result in an incidence of $103 \%$, suggesting every 
cow has elevated milk BHB in early lactation. Such an incidence risk would be surprising, as other studies that tested cows on a frequent-sampling protocol all report that some cows get through the early lactation period without elevated BHB concentrations (Duffield et al., 2009; McArt et al., 2012; Vanholder et al., 2015). As mentioned earlier, whether or not the blood incidenceto-prevalence factor can be applied directly to milk BHB concentrations has not been determined. Nevertheless, as suggested by McArt et al. (2012), prevalence itself is a useful tool for herd monitoring over time as well as an outcome indicator for changes in dry or postparturient cow management practices, and results from our study suggest milk BHB concentration can serve this purpose.

Several studies have reported an increase in the prevalence or odds of hyperketonemia with increasing parity (McArt et al., 2013; Vanholder et al., 2015). Mahrt et al. (2015) reported mean prevalences of 7.0, 6.6 , and $17.6 \%$ in cows of first, second, and third and greater lactation, respectively; these values are lower than in the present study. To our knowledge no one has reported a different prevalence curve in relation to DIM for different parities, as illustrated in Figure 1. The high prevalence for first-lactation cows in the first days of lactation is surprising compared with results from the literature, and could indicate either a lack of preparation for heifers entering their first lactation or a much-higher-than-expected stress level associated with calving, the onset of lactation, and the entry in the lactating herd. It is not excluded that this difference could also be due to the fact that milk BHB rather than blood BHB were analyzed in the present study, and that the distribution of BHB in milk could differ between primiparous and multiparous cows. Further investigation is required to identify potential factors for this high prevalence.

Although ketosis is recognized as an early-lactation disorder and most studies suggest to measure ketone concentration only in the first DIM, generally up to 14 DIM (McArt et al., 2012; Ospina et al., 2013), our results clearly show that prevalence of elevated milk BHB is still above $15 \%$ even past 35 DIM. Herds involved in previous studies are much larger that the median herd size of the present study (1,000 compared with 62 cows), and management styles involved in these herds might be a main reason for the difference in risk period. Our results strongly suggest that testing for elevated milk BHB should be extended to longer than the first $3 \mathrm{wk}$ of lactation. This is also supported by Mahrt et al. (2015), who stated that the risk period for hyperketonemia lasts at least until 42 DIM. One limitation of our study is the fact that our data are from monthly DHI milk samples, which do not allow confirmation of whether or not SUSP or POS cows around 35 DIM were positive earlier in lactation. Recent literature reports that hyperketonemia cases last on average 3 to 5 d (McArt et al., 2012; Mahrt et al., 2015), whereas Dohoo and Martin (1984) suggested durations of $7.9 \mathrm{~d}$. In addition to management practices differing according to herd size, different sampling frequency protocols and testing periods with regard to DIM are possible explanations for the differences among studies.

Severity of the effects of elevated BHB vary depending on DIM at the onset of the hyperketonemia case. McArt et al. (2012) reported increased culling, decreased conception, and lower milk production for cows testing positive for the first time in the first week of lactation compared with cows testing positive for the first time at DIM 8 or later. Unfortunately, it was not possible to determine the DIM at onset of elevated milk BHB in the present study due to the frequency of sample collection.

\section{Seasonal Prevalence}

Figure 2 reveals a seasonal pattern in prevalence of elevated milk BHB from October 2011 to October 2015. Cows calving in late fall (October to January) and spring (April to June) seasons showed a slightly higher prevalence of elevated milk BHB in the first $35 \mathrm{~d}$ of lactation. However, the small difference in prevalence between seasons probably has no biological effect on the dairy cows and herds.

\section{Herd Prevalence}

Only herds with more than 20 cows tested for BHB between 5 and 35 DIM were included in this herd

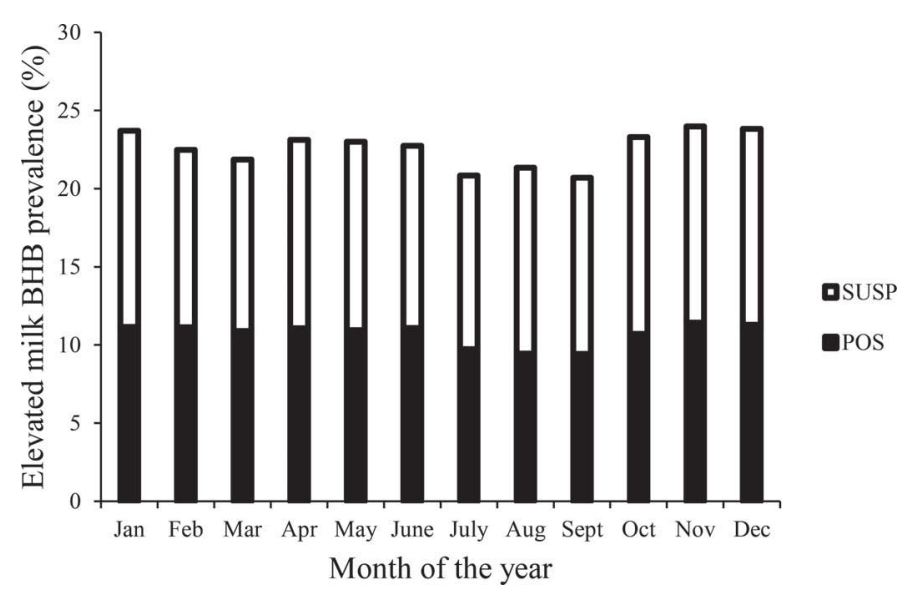

Figure 2. Prevalence of elevated milk BHB in early-lactation Holstein cows (5-35 DIM) according to month of calving. SUSP (suspect) $=$ milk BHB 0.15 to $0.19 \mathrm{mmol} / \mathrm{L} ;$ POS (positive) $=$ milk BHB $\geq 0.20 \mathrm{mmol} / \mathrm{L}$. Number of cows sampled $=498,310$ from 4,242 herds. 
prevalence analysis. Distribution of herd prevalence reveals that herds have on average $23.6 \pm 0.19 \%$ (mean \pm SEM) of cows with elevated milk BHB concentration (BHB $\geq 0.15 \mathrm{mmol} / \mathrm{L}$ ) in early lactation. As illustrated in Figure 3, distribution among herds varies greatly: $9.2 \%$ of herds have a prevalence of $10 \%$ or less; $35.9 \%$ of herds have a prevalence between 11 and $20 \% ; 47.1 \%$ of herds have a prevalence between 21 and $40 \% ; 5.9 \%$ of herds have a prevalence between 41 and $50 \%$; and $1.9 \%$ of herds have a prevalence of $51 \%$ or above. Possible reasons for variations in distribution among herds are feeding strategies, genetic variation, milk yield, dry cow and early-lactation cow nutrition and management, gestating heifer management, prevention strategies used on farms, as well as incidence of other diseases (Oetzel, 2004; Ingvartsen, 2006; Roche et al., 2009; van der Drift et al., 2012; Koeck et al., 2014a).

Overall early lactation (DIM 2 to 15 ) prevalence reported by Suthar et al. (2013) was $21.8 \%$, with minimum and maximum country prevalence of, respectively, 11.2 and $36.6 \%$. Chapinal et al. (2012) reported that the prevalence of herds in which more than $25 \%$ of sampled cows had increased postpartum BHB concentrations of $1.4 \mathrm{mmol} / \mathrm{L}$ or greater within a week postpartum was $15 \%$ in 55 herds in the United States and Canada; these values are similar to the current analysis of herd prevalence.

As mentioned previously, monthly testing for BHB through the DHI milk sample is simple and inexpensive, but has the limitation of missing many cows between tests. This monthly prevalence, however, is still a good indicator of BHB status in the herd and is a useful herd-level monitoring tool. Within-herd alarm thresholds reported in the literature suggest that herds with 15 to $25 \%$ of sampled animals having increased postpartum BHB concentrations may have increased risks of postpartum diseases, poorer reproduction, and lower milk production than herds with a lower proportion of positive animals (Ospina et al., 2010a; Chapinal et al., 2012). In the present data set, $55.0 \%$ of herds have a prevalence $\geq 20 \%$ and would therefore be above this threshold and at risk for health, reproduction, and production issues.

\section{Effects on Milk Production and Components}

Effects of early-lactation elevated milk BHB on testday measures are presented in Table 1. Milk yield on test day was highest for NEG cows in all parity groups. On average, NEG cows were producing $2.33 \pm 0.04$ $\mathrm{kg} / \mathrm{d}$ more than POS cows and $0.12 \pm 0.04 \mathrm{~kg} / \mathrm{d}$ more than SUSP cows $(P \leq 0.003)$. Our results suggest that elevated milk BHB in early lactation is associated with lower milk yield on test day (Table 1). Dohoo and Mar-

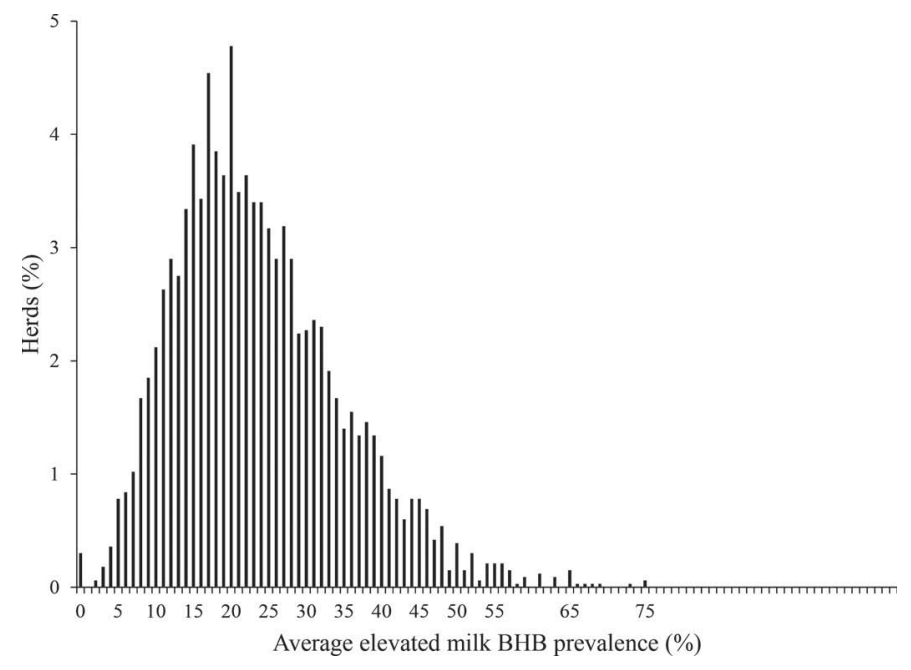

Figure 3. Distribution of elevated milk BHB prevalence among herds. Prevalence includes cows with milk BHB concentrations $\geq 0.15$ mmol/L. Only herds with more than 20 cows tested between 5 and 35 DIM over the experimental period are reported $(\mathrm{n}=3,349)$.

tin (1984) and Duffield et al. (2009) have previously reported 1.0 to $1.9 \mathrm{~kg} / \mathrm{d}$ lower test-day milk yield for cows with higher BHB concentrations, which is slightly lower than the difference observed in the present analysis. More recently, Chapinal et al. (2012) and McArt et al. (2012) reported a reduction in daily milk yield ranging from 1.2 to $2.4 \mathrm{~kg} / \mathrm{d}$ for hyperketonemic cows. McArt et al. (2012) generated an equation to predict daily milk yield based on blood BHB concentration at the first positive test. For each $0.1 \mathrm{mmol} / \mathrm{L}$ increase in BHB concentration at the first positive test, the predicted milk produced for the first 30 DIM was decreased by $0.5 \mathrm{~kg} / \mathrm{d}$, suggesting a linear relationship between blood BHB concentration and milk yield. Production of ECM in the present study was highest for SUSP cows for all parity groups $(P<0.001)$, reflecting the effect on milk components discussed later.

Previous studies have suggested a different association between hyperketonemia and milk production based on parity and DIM at diagnosis. It was suggested that cows developing hyperketonemia in the first week postpartum had a lower milk production than cows that developed hyperketonemia after the first week of lactation (McArt et al., 2012). Analysis of our data for milk yield by week relative to calving revealed that the difference in milk yield between NEG and POS cows increased with increasing weeks of lactation (Figure 4). Cows classified as POS in wk 1 to 5 of lactation produced, respectively, 95.9, 94.9, 93.4, 91.9, and $91.2 \%$ of milk produced by NEG cows. Effect of elevated earlylactation milk BHB on complete-lactation milk yield has not been evaluated in the current study, and it is not possible to assess if this has long-term effects. 


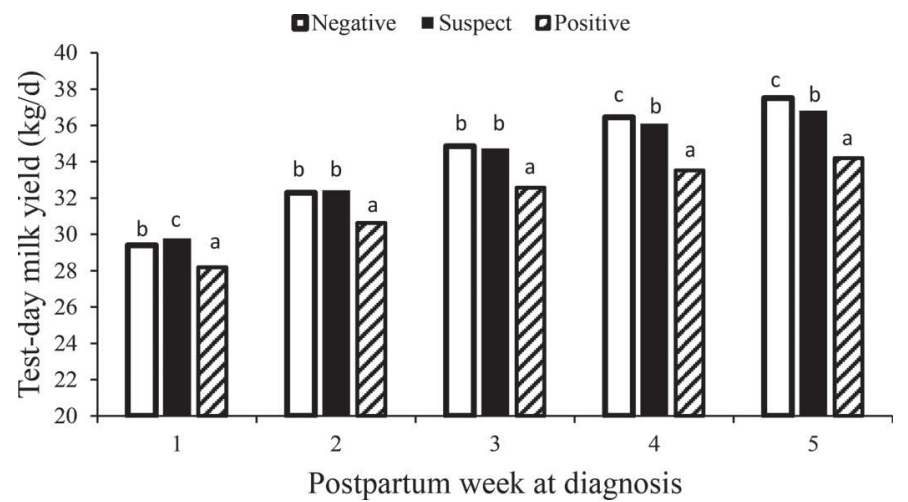

Figure 4. Test day milk yield for cows according to milk BHB concentration and week relative to calving on which diagnosis was performed. Negative $=$ milk BHB $<0.15 \mathrm{mmol} / \mathrm{L}$; Suspect $=$ milk BHB 0.15 to $0.19 \mathrm{mmol} / \mathrm{L}$; Positive $=$ milk $\mathrm{BHB} \geq 0.20 \mathrm{mmol} / \mathrm{L}$. Mean SE $=0.11 \mathrm{~kg} / \mathrm{d}$. Number of cows sampled $=498,310$ from 4,242 herds. Different letters $(\mathrm{a}-\mathrm{c})$ within the same week of lactation represent significant differences $(P<0.001)$.

As mentioned previously, one important limitation from our analysis is the monthly testing frequency, which did not allow us to evaluate whether cows positive at a given time point in lactation were previously positive or not. However, the current data illustrate that negative effects are still associated with elevated milk BHB even if the diagnosis takes place in the fifth week postcalving.

Fat percentage was highest for POS cows. Difference between POS and NEG cows was $0.95 \pm 0.01 \%$ ( $P$ $<0.001$ ) for all parity groups, with SUSP cows having intermediate concentrations (Table 1). This is in accordance with the higher fat mobilization leading to increased NEFA carried to the liver and partially oxidized (resulting in increased BHB production) or carried directly to the mammary gland and exported in milk. Increased fat concentration in milk from hyperketotic cows has been reported by Duffield et al. (2009), but is often not mentioned in other trials. As a result, fat yield was also increased in SUSP and POS multiparous cows, although we found no difference in fat yield between these 2 categories for first-lactation cows (Table 1).

Protein percentage was lowest for SUSP cows and highest for NEG cows in all parity groups. Interestingly, the difference between NEG and SUSP cows was $0.10 \pm 0.01,0.05 \pm 0.01$, and $0.05 \pm 0.01 \%(P<0.001)$ for cows in first, second, and third or greater lactation, respectively. It is not known why the effect was greater for first-parity cows. Negative effects of high BHB on protein concentration in milk had been reported by Duffield et al. (2009), who observed a decrease of $0.09 \%$ between hyperketotic and nonketotic cows. This is consistent with the known positive association between energy balance and milk protein concentration (Grieve et al., 1986); effect of parity was not discussed by Duffield et al. (2009). Protein yield was highest for NEG cows and lowest for POS cows (difference of $0.09 \pm 0.01$ $\mathrm{kg} / \mathrm{d} ; P<0.001$ ), with SUSP cows having intermediate values. Fat-to-protein ratio was highest for POS cows, in agreement with the fat and protein results presented here and indicating a higher level of fat mobilization and excretion in milk for cows with elevated BHB concentrations. Correlation coefficient between milk BHB

Table 1. Milk and component yields according to parity and milk BHB status for 498,310 cows sampled at first DHI test (DIM 5-35)

\begin{tabular}{|c|c|c|c|c|c|c|c|c|c|c|}
\hline \multirow[b]{2}{*}{ Variable $^{1}$} & \multicolumn{3}{|c|}{ First lactation $^{2}$} & \multicolumn{3}{|c|}{ Second lactation $^{2}$} & \multicolumn{3}{|c|}{ Third or greater lactation $^{2}$} & \multirow[b]{2}{*}{$\mathrm{SE}$} \\
\hline & NEG & SUSP & POS & NEG & SUSP & POS & NEG & SUSP & POS & \\
\hline Number of cows & 130,609 & 16,283 & 13,661 & 107,034 & 14,552 & 11,328 & 148,271 & 28,407 & 28,165 & \\
\hline $\operatorname{Milk}(\mathrm{kg} / \mathrm{d})$ & $29.1^{\mathrm{b}}$ & $28.9^{\mathrm{b}}$ & $27.0^{\mathrm{a}}$ & $38.0^{\mathrm{e}}$ & $37.9^{\mathrm{e}}$ & $35.7^{\mathrm{d}}$ & $39.9^{\mathrm{i}}$ & $39.6^{\mathrm{h}}$ & $36.9^{\mathrm{g}}$ & 0.2 \\
\hline $\operatorname{ECM}(\mathrm{kg} / \mathrm{d})$ & $29.5^{\mathrm{a}}$ & $30.8^{\mathrm{c}}$ & $30.1^{\mathrm{b}}$ & $38.1^{\mathrm{d}}$ & $40.0^{\mathrm{f}}$ & $39.5^{\mathrm{e}}$ & $40.1^{\mathrm{g}}$ & $42.2^{\mathrm{i}}$ & $41.3^{\mathrm{h}}$ & 0.2 \\
\hline Fat $(\%)$ & $4.12^{\mathrm{a}}$ & $4.66^{\mathrm{b}}$ & $5.07^{\mathrm{c}}$ & $4.06^{\mathrm{d}}$ & $4.52^{\mathrm{e}}$ & $4.94^{\mathrm{f}}$ & $4.10^{\mathrm{g}}$ & $4.61^{\mathrm{h}}$ & $5.08^{\mathrm{i}}$ & 0.02 \\
\hline Fat $(\mathrm{kg} / \mathrm{d})$ & $1.20^{\mathrm{a}}$ & $1.33^{\mathrm{b}}$ & $1.34^{\mathrm{c}}$ & $1.53^{\mathrm{d}}$ & $1.69^{\mathrm{e}}$ & $1.73^{\mathrm{f}}$ & $1.62^{\mathrm{g}}$ & $1.80^{\mathrm{h}}$ & $1.83^{\mathrm{i}}$ & 0.01 \\
\hline Protein $(\%)$ & $3.23^{\mathrm{c}}$ & $3.13^{\mathrm{a}}$ & $3.14^{\mathrm{b}}$ & $3.28^{\mathrm{f}}$ & $3.23^{\mathrm{d}}$ & $3.25^{\mathrm{e}}$ & $3.25^{\mathrm{i}}$ & $3.20^{\mathrm{g}}$ & $3.24^{\mathrm{h}}$ & 0.01 \\
\hline Protein $(\mathrm{kg} / \mathrm{d})$ & $0.93^{\mathrm{c}}$ & $0.90^{\mathrm{b}}$ & $0.84^{\mathrm{a}}$ & $1.23^{\mathrm{f}}$ & $1.21^{\mathrm{e}}$ & $1.15^{\mathrm{d}}$ & $1.28^{\mathrm{i}}$ & $1.26^{\mathrm{h}}$ & $1.18^{\mathrm{g}}$ & 0.01 \\
\hline Lactose $(\%)$ & $4.64^{\mathrm{c}}$ & $4.55^{\mathrm{b}}$ & $4.47^{\mathrm{a}}$ & $4.57^{\mathrm{f}}$ & $4.52^{\mathrm{e}}$ & $4.46^{\mathrm{d}}$ & $4.52^{\mathrm{i}}$ & $4.46^{\mathrm{h}}$ & $4.39^{\mathrm{g}}$ & 0.01 \\
\hline Lactose $(\mathrm{kg} / \mathrm{d})$ & $1.35^{\mathrm{c}}$ & $1.32^{\mathrm{b}}$ & $1.21^{\mathrm{a}}$ & $1.74^{\mathrm{f}}$ & $1.72^{\mathrm{e}}$ & $1.61^{\mathrm{d}}$ & $1.81^{\mathrm{i}}$ & $1.78^{\mathrm{h}}$ & $1.63^{\mathrm{g}}$ & 0.01 \\
\hline $\mathrm{F}: \mathrm{P}$ ratio $^{3}$ & $1.29^{\mathrm{a}}$ & $1.50^{\mathrm{b}}$ & $1.62^{\mathrm{c}}$ & $1.24^{\mathrm{d}}$ & $1.41^{\mathrm{e}}$ & $1.53^{\mathrm{f}}$ & $1.27^{\mathrm{g}}$ & $1.45^{\mathrm{h}}$ & $1.58^{\mathrm{i}}$ & 0.1 \\
\hline MUN (mg of N/dL) & $10.7^{\mathrm{c}}$ & $10.2^{\mathrm{b}}$ & $9.4^{\mathrm{a}}$ & $10.9^{f}$ & $10.4^{\mathrm{e}}$ & $9.4^{\mathrm{d}}$ & $10.2^{\mathrm{i}}$ & $9.5^{\mathrm{h}}$ & $8.5^{\mathrm{g}}$ & 0.1 \\
\hline $\mathrm{SCC}\left(\times 10^{3}\right.$ cells $\left./ \mathrm{mL}\right)$ & $193^{\mathrm{a}}$ & $248^{\mathrm{b}}$ & $277^{\mathrm{c}}$ & $191^{\mathrm{d}}$ & $262^{\mathrm{e}}$ & $292^{\mathrm{f}}$ & $300^{\mathrm{g}}$ & $402^{\mathrm{h}}$ & $484^{\mathrm{i}}$ & 23 \\
\hline SCS & $2.55^{\mathrm{a}}$ & $2.76^{\mathrm{b}}$ & $2.83^{\mathrm{c}}$ & $2.35^{\mathrm{d}}$ & $2.61^{\mathrm{e}}$ & $2.68^{\mathrm{f}}$ & $2.86^{\mathrm{g}}$ & $3.12^{\mathrm{h}}$ & $3.28^{\mathrm{i}}$ & 0.06 \\
\hline TCI & $\mathrm{NA}^{4}$ & NA & $\mathrm{NA}$ & $167^{\mathrm{e}}$ & $175^{\mathrm{e}}$ & $-82^{\mathrm{d}}$ & $332^{\mathrm{h}}$ & $328^{\mathrm{h}}$ & $16^{\mathrm{g}}$ & 42 \\
\hline
\end{tabular}

${ }^{\mathrm{a}-\mathrm{i}}$ Means within the same parity group with different superscripts are significantly different $(P \leq 0.05)$.

${ }^{1} \mathrm{BHB}$, parity, DIM, calving month effects, and BHB $\times$ parity $(P<0.0001)$.

${ }^{2} \mathrm{NEG}$ (negative) $=$ milk BHB $<0.15 \mathrm{mmol} / \mathrm{L}$; SUSP (suspect) $=$ milk BHB $0.15-0.19 \mathrm{mmol} / \mathrm{L} ; \mathrm{POS}(\mathrm{positive})=\mathrm{milk} \mathrm{BHB} \geq 0.20 \mathrm{mmol} / \mathrm{L}$.

${ }^{3}$ Fat-to-protein ratio.

${ }^{4}$ Not applicable; Transition Cow Index calculated for multiparous cows only (Nordlund, 2006). 
concentration and fat-to-protein ratio was $-0.89(P<$ $0.001)$.

Lactose and MUN concentrations were both lowest for POS cows and highest for NEG cows in all parity groups, with SUSP cows having intermediate results (Table 1). Average difference between NEG and POS cows for lactose concentration and lactose yield were, respectively, $0.14 \pm 0.01 \%$ and $0.15 \pm 0.01 \mathrm{~kg} / \mathrm{d}(P$ $<0.001)$. A decrease in lactose concentration is often associated with a loss of integrity of the tight junctions (Pierre Lacasse, Agriculture and Agri-Food Canada, Sherbrooke, Quebec, Canada, personal communication), which correlates with the increased SCS (see below) and decreased lactose concentrations for POS cows observed in our study. Differences in MUN concentrations for NEG and POS cows were $1.3 \pm 0.1,1.5$ \pm 0.1 , and $1.7 \pm 0.1 \mathrm{mg}$ of $\mathrm{N} / \mathrm{dL}(P<0.001)$ for cows in first, second, and third or greater lactation, respectively. Using a portion of the present data set $(41,500$ records of first-lactation cows), Koeck et al. (2014b) found no significant genetic association between first and second test-day BHB and MUN and lactose concentrations. To our knowledge, no other recent studies have presented effects of elevated milk or blood BHB on lactose and MUN concentrations. However, it has been demonstrated that subclinical ketosis was associated with lower DMI (Goldhawk et al., 2009), which suggests that protein intake was also lower in POS cows than in NEG cows. This lower protein intake could explain the lower protein and MUN concentrations in milk of POS cows observed in the present study. The design of our study did not allow us to measure DMI, and this hypothesis needs to be validated.

Somatic cell count and SCS were highest in POS cows $(P<0.001$; Table 1$)$. Negative effects of hyperketonemia on immunity have been reported elsewhere (Hammon et al., 2006), but not with increased risks for mastitis (Suthar et al., 2013). In fact, LeBlanc (2010) reported that hyperketonemia in the first 2 wk postpartum did not affect the incidence of clinical mastitis, but increased the severity and duration of clinical mastitis, which is consistent with the elevation of SCC in the current study. Recently, Koeck et al. (2014a) concluded that selecting for lower milk BHB in early lactation would lead to an improvement of SCS. On the other hand, the review by Raboisson et al. (2014) suggested odds ratios of 1.61 for clinical mastitis and 1.42 for high SCC for hyperketonemic cows. Clinical mastitis was not assessed in the present study.

Although milk yield and components can be used to analyze performance and status of early-lactation cows, a tool was recently developed to objectively evaluate the success of transition (TCI; Nordlund, 2006). This index is calculated only for multiparous cows and com- pares first test-day production level to a prediction calculated based on several parameters, including previous lactation yield, last test-day SCS, parity, season, dry period length, and breed. A positive TCI indicates a better-than-expected milk yield at first test indicative of favorable health status, whereas a negative TCI value implies transition issues and negatively affected early-lactation milk yield. In the present trial, NEG and SUSP cows had a positive TCI value, whereas the result was negative for POS cows. This result suggests that SUSP and NEG cows had a slightly better than average lactation start based on their first test-day milk yield, whereas POS cows had lower-than-expected milk yields on that first test day. It should be noted that the overall average for TCI is higher than 0 , because the reference population for the calculation is the 2005 Wisconsin population of cows. Current TCI average in eastern Canada is 131 (Valacta, 2016). Transition Cow Index values for various BHB concentrations in milk have not been published elsewhere.

\section{CONCLUSIONS}

Results from the present study highlight that elevated milk BHB is a common early-lactation disorder in the eastern Canada dairy cow population, with negative effects on test-day performance. Prevalence is affected by parity and season of calving. Individual herds show a large range in prevalence, probably due to differences in management and feeding. The main limitation of this study resides in the frequency of sampling, as BHB concentration has been evaluated in monthly DHI milk samples. However, assessing BHB concentrations in DHI samples to determine prevalence of herd-level elevated milk BHB is rapid, inexpensive, and requires no additional efforts and labor. It can be used as a monitoring tool to control the success of management programs at the herd level. It can be combined to individual cow-side tests to support decisions at the individual cow level as to whether cows should be treated or not. Further studies should look at the effects of elevated early-lactation BHB in milk on complete lactation performance, as well as on other health and reproductive aspects.

\section{REFERENCES}

Chapinal, N., S. J. LeBlanc, M. E. Carson, K. E. Leslie, S. Godden, M. Capel, J. E. Santos, M. W. Overton, and T. F. Duffield. 2012. Herd-level association of serum metabolites in the transition period with disease, milk production, and early lactation reproductive performance. J. Dairy Sci. 95:5676-5682.

de Roos, A. P., H. J. van den Bijgaart, J. Horlyk, and G. de Jong. 2007. Screening for subclinical ketosis in dairy cattle by Fourier transform infrared spectrometry. J. Dairy Sci. 90:1761-1766. 
Denis-Robichaud, J., J. Dubuc, D. Lefebvre, and L. DesCôteaux. 2014. Accuracy of milk ketone bodies from flow-injection analysis for the diagnosis of hyperketonemia in dairy cows. J. Dairy Sci. 97:3364-3370.

Dohoo, I. R., and S. W. Martin. 1984. Subclinical ketosis: Prevalence and associations with production and disease. Can. J. Comp. Med. $48: 1-5$.

Duffield, T. F., K. D. Lissemore, B. W. McBride, and K. E. Leslie. 2009. Impact of hyperketonemia in early lactation dairy cows on health and production. J. Dairy Sci. 92:571-580.

Duffield, T. F., D. Sandals, K. E. Leslie, K. Lissemore, B. W. McBride, J. H. Lumsden, P. Dick, and R. Bagg. 1999. Efficacy of Monensin for the prevention of subclinical ketosis in lactating dairy cows. J. Dairy Sci. 81:2866-2873.

Foss. 2009. Foss Application Note 35. MilkoScan FT+ Ketosis Calibrations. Foss, Hillerød, Denmark.

Garro, C. J., L. Milan, and M. Cobos Roldán. 2014. Subclinical ketosis in dairy cows: Prevalence and risk factors in grazing production system. J. Anim. Phys. Anim. Nutr. 98:838-844.

Goldhawk, C., N. Chapinal, D. M. Veira, D. M. Weary, and M. A. G. von Keyserlingk. 2009. Prepartum feeding behavior is an early indicator of subclinical ketosis. J. Dairy Sci. 92:4971-4977.

Grieve, D. G., S. Korver, Y. S. Rijpkema, and G. Hof. 1986. Relationship between milk composition and some nutritional parameters in early lacatation. Livest. Prod. Sci. 14:239-254.

Hammon, D. S., I. M. Evjen, T. R. Dhiman, J. P. Goff, and J. L. Walters. 2006. Neutrophil function and energy status in Holstein cows with uterine health disorders. Vet. Immunol. Immunopathol. 113:21-29.

Herdt, T. H. 2000. Ruminant adaptation to negative energy balance. Influences on the etiology of ketosis and fatty liver. Vet. Clin. North Am. Food Anim. Pract. 16:215-230.

Ingvartsen, K. L. 2006. Feeding- and management-related diseases in the transition cow. Physiological adaptations around calving and strategies to reduce feeding-related diseases. Anim. Feed Sci. Technol. 126:175-213.

Itle, A. J., J. M. Huzzey, D. M. Weary, and M. A. G. von Keyserlingk. 2015. Clinical ketosis and standing behavior in transition cows. J. Dairy Sci. 98:128-134.

Iwersen, M., U. Falkenberg, R. Voigtsberger, D. Forderung, and W. Heuwieser. 2009. Evaluation of an electronic cowside test to detect subclinical ketosis in dairy cows. J. Dairy Sci. 92:2618-2624.

Koeck, A., J. Jamrozik, F. S. Schenkel, R. K. Moore, D. M. Lefebvre, D. F. Kelton, and F. Miglior. 2014a. Genetic analysis of milk $\beta$-hydroxybutyrate and its association with fat-to-protein ratio, body condition score, clinical ketosis, and displaced abomasum in early first lactation of Canadian Holsteins. J. Dairy Sci. 97:72867292 .

Koeck, A., J. Jamrozik, F. S. Schenkel, R. K. Moore, D. M. Lefebvre, D. F. Kelton, and F. Miglior. 2014b. Genetic and phenotypic relationships of milk $\beta$-hydroxybutyrate with milk production and fertility traits in Canadian Holsteins. DCBG Sept. 2014. Accessed June 12, 2016. http://cgil.uoguelph.ca/dcbgc/Agenda1409/ Astrid\%20BHB\&Fertility\%20DCBGC.pdf.

LeBlanc, S. 2010. Monitoring metabolic health of dairy cattle in the transition period. J. Reprod. Dev. 56(Suppl.):S29-S35.

LeBlanc, S. J., K. E. Leslie, and T. F. Duffield. 2005. Metabolic predictors of displaced abomasum in dairy cattle. J. Dairy Sci. $88: 159-170$.

Mahrt, A., O. Burfeind, and W. Heuwieser. 2015. Evaluation of hyperketonemia risk period and screening protocols for early-lactation dairy cows. J. Dairy Sci. 98:3110-3119.

McArt, J. A. A., D. V. Nydam, and G. R. Oetzel. 2012. Epidemiology of subclinical ketosis in early lactation dairy cattle. J. Dairy Sci. 95:5056-5066.
McArt, J. A. A., D. V. Nydam, and G. R. Oetzel. 2013. Dry period and parturient predictors of early lactation hyperketonemia in dairy cattle. J. Dairy Sci. 96:198-209.

McArt, J. A. A., D. V. Nydam, and M. W. Overton. 2015. Hyperketonemia in early lactation dairy cattle: A deterministic estimate of component and total cost per case. J. Dairy Sci. 98:2043-2054.

Nordlund, K. 2006. Transition Cow Index. Pages 139-143 in 39th Proc. Am. Assoc. Bovine Pract., St. Paul, MN. Am. Assoc. Bovine Pract., Auburn, AL.

NRC. 2001. Nutrient Requirements of Dairy Cattle. 7th ed. Natl. Acad. Press, Washington, DC.

Oetzel, G. R. 2004. Monitoring and testing dairy herds for metabolic disease. Vet. Clin. North Am. Food Anim. Pract. 20:651-674.

Ospina, P. A., J. A. McArt, T. R. Overton, T. Stokol, and D. V. Nydam. 2013. Using nonesterified fatty acids and $\beta$-hydroxybutyrate concentrations during the transition period for herd-level monitoring of increased risk of disease and decreased reproductive and milking performance. Vet. Clin. North Am. Food Anim. Pract. 29:387-412.

Ospina, P. A., D. V. Nydam, T. Stokol, and T. R. Overton. 2010a. Associations of elevated nonesterified fatty acids and beta-hydroxybutyrate concentrations with early lactation reproductive performance and milk production in transition dairy cattle in the Northeastern United States. J. Dairy Sci. 93:1596-1603.

Ospina, P. A., D. V. Nydam, T. Stokol, and T. R. Overton. 2010b. Evaluation of nonesterified fatty acids and $\beta$-hydroxybutyrate in transition dairy cattle in the northeastern United States: Critical thresholds for prediction of clinical diseases. J. Dairy Sci. 93:546554.

Pineda, A., and F. C. Cardoso. 2015. Technical note: Validation of a handheld meter for measuring $\beta$-hydroxybutyrate concentrations in plasma and serum from dairy cows. J. Dairy Sci. 98:8818-8824.

Raboisson, D., M. Mounié, and E. Maigné. 2014. Diseases, reproductive performance, and changes in milk production associated with subclinical ketosis in dairy cows: A meta-analysis and review. J. Dairy Sci. 97:7547-7563.

Roche, J. R., N. C. Friggens, J. K. Kay, M. W. Fisher, K. J. Stafford, and D. P. Berry. 2009. Invited review: Body condition score and its association with dairy cow productivity, health, and welfare. J. Dairy Sci. 92:5769-5801.

Seifi, H. A., S. J. LeBlanc, K. E. Leslie, and T. F. Duffield. 2011. Metabolic predictors of post-partum disease and culling risk in dairy cattle. Vet. J. 188:216-220.

Suthar, V. S., J. Canelas-Raposo, A. Deniz, and W. Heuwieser. 2013. Prevalence of subclinical ketosis and relationships with postpartum diseases in European dairy cows. J. Dairy Sci. 96:2925-2938.

Tyrrell, H. F., and J. T. Reid. 1965. Prediction of the energy value of cow's milk. J. Dairy Sci. 48:1215-1223.

Valacta. 2016. Évolution de la production laitière québécoise 2015. Publié en collaboration avec Le Producteur de Lait Québécois. Numéro spécial. Juin 2016. Longueuil, Quebec, Canada.

van der Drift, S. G. A., K. J. E. van Hulzen, T. G. Teweldemedhn, R. Jorritsma, M. Nielen, and H. C. M. Heuven. 2012. Genetic and nongenetic variation in plasma and milk $\beta$-hydroxybutyrate and milk acetone concentrations of early-lactation dairy cows. J. Dairy Sci. 95:6781-6787.

Vanholder, T., J. Papen, R. Bermers, G. Vertenten, and A. C. B Berge. 2015. Risk factors for subclinical and clinical ketosis and association with production parameters in dairy cows in the Netherlands. J. Dairy Sci. 98:880-888.

Walsh, R. B., J. S. Walton, D. F. Kelton, S. J. LeBlanc, K. E. Leslie, and T. F. Duffield. 2007. The effect of subclinical ketosis in early lactation on reproductive performance of postpartum dairy cows J. Dairy Sci. 90:2788-2796. 